\title{
Application Pis (Indonesia Wellness Progrsam) PK Model with Decision and Matriarchal Patriarchal Family of Compliance on the Family of the Suffering of Disease TB Lung Health in the Work Remu City Sorong
}

\author{
Maria Loihala \\ Poltekkes Ministry of Health Sorong
}

\begin{abstract}
Background : Indonesia Healthy Family Approach (PIS PK) is done by visiting the family, with the target and the target is a PK PIS family. Indonesia has a health problem that is in the public spotlight in 2018, namely the high number of cases of pulmonary tuberculosis (TB). Based on 2016 WHO Global Tuberculosis Report, Indonesia ranks second with the highest TB burden in the world. This includes many cases that have not been detected and have not been treated and have not been reported. In the family structure and cultural dimensions based on decision making known as Patriakal and Matriakal. By knowing the pattern of household decision making, it can also be seen whether there is dominance in a household.
\end{abstract}

The Research Objective : Knowing overview and analyze the application of PIS PK (Healthy Indonesia Program) model of decision making patriarchal and matriarchal families on treatment compliance in family members who suffer from pulmonary tuberculosis in Puskesmas Remu Sorong.

Research design : Quantitative and qualitative research. Quantitative research method is case control design The qualitative research method is phenemoenology . The population in this study is the manager of the PK PIS program and all family members who suffer from TB in the work area of the Remu Puskesmas in Sorong City. The sample in this study amounted to 32 respondents.

Results : They have been done and they have the document but not maximum home visits, and patients taking the medicine lazy. Test using the Old Ratio (OR) with an estimate of 8.333 means that the application of PIS PK in accordance with the guidelines on matriarchal decision making is 8 times the risk of being folded from patriarchal decision making. The implementation of PIS PK in accordance with the guidelines for medication compliance 10 times the risk of compliance with treatment compliance .

Conclusion : Application of PIS PK has documents, but not optimal, PIS Application of PK with decision model testing friendly old ratio of 8 times the risk in decision-making, and PK of the compliance application PIS treatment 10-fold risk of adherent treatment. Suggestions for community health centers as a result of data collection to the community to discuss further interventions and empower the community.

Keywords : Application of PIS (Program Healthy Indonesia) PK, Model Making

\section{Introduction}

The Healthy Indonesia Program with a Family Approach (PIS PK) is carried out by visiting families, and the target of PIS PK being families. Family approach support the achievement of healthy Indonesia program ${ }^{1}$.
In PIS-PK has been set twelve major indicator as a marker of health status of a family that includes the family followed the family planning program, deliver at a health facility, the baby gets fully immunized, infants received breast milk (ASI) exclusive, toddler get growth monitoring, tuberculosis patient pulmonary receive treatment according to standard, people with 
hypertension take medication regularly, people with mental disorders receive treatment and neglect, family members no one smokes, the family has become a member of the National Health Insurance (JKN), the family has access to clean water facilities, families have access to or use a toilet. The Government may establish addition indicator to principal indicator in accordance with the conditions and needs of the region so that West Papua add one indicator is the examination and treatment of malaria, according to the standard so that, in West Papua has become a healthy thirteen indicators ${ }^{1}$.

Based on 2016 WHO Global Tuberculosis Report, Indonesia ranks second with the highest TB burden in the world ${ }^{2}$.

Globally in 2016 there were 10.4 million TB incident cases ( 8.8 million - 12, million) which is equivalent to 120 cases per 100,000 population. WHO data in 2017 Indonesia ranks third highest sufferers. The number of new TB cases in Indonesia was 420,994 cases in $2017^{3}$.

Data and information from the province of West Papua show that the number of cases of all types was 1921 cases, the highest in 658 cases in Manokwari, while in Kota Sorong it was 332 cases and. Of these, there were 1061 new positive BTA tuberculosis cases $\square$.

The results of the focus group discussions (puskesmas staff) most of the informants stated that the personnel involved in the data collection of PIS-PK at the puskesmas who had been running PIS-PK had not yet received a decree as PIS-PK implementer. The data collection officer is only given a special assignment letter. Most informants objected to the policy requiring HR in all puskesmas involved in the collection of PISPK to have attended training.
In the family structure and cultural dimensions based on decision making known as Patriakal and Matriakal. Patriarchal is a condition where decision making by the husband or the husband's extended family. While matriacal is a household condition where decision making is on the part of his wife or extended family $\square$.

The family approach is one way to increase the reach of targets and bring closer/improve access to health services in the work area by visiting $\square$.

Puskesmas Remu Sorong city is one health center under the Government of Sorong that organizer outdoor activities building one by direct observation of spaciousness which is the implementation of the Indonesia Program Healthy Approach Family (PISPK). The total residents of four villages that 31,532 inhabitants. Of these, until March 2018 there were 15 TB positive people. Meanwhile those with suspected tuberculosis recorded 57 people. In 2019 there were 48 patients suffering from positive pulmonary TB. as for the application of PIS PK through new manager 2018 year program is applied in South Remu village, and in 2019 will be carried out in Sub Malabutor ${ }^{7}$.

\section{Materials and Method}

This type of research is a mixed research that is quantitative and qualitative. Quantitative research methods that use case control design. Qualitative research methods with using a phenomenological approach .

Finansial Source: The source of funding in this study is DIPA Poltekkes Sorong 2019.

\section{Research Results}

\section{Table 1. Characteristics of Respondents}

Table 1. shows the many aged 31-40 years (31.2\%), most of the male sex (62.5\%), Education least a lot of high school (37.6\%) and most work as self-employed (40.6\%).

\section{Univariate Analysis}


Table 2. Frequency Distribution According To The Application Of Respondent PK PIS

\begin{tabular}{|l|l|l|l|}
\hline No & Lung TB & Amount & $\%$ \\
\hline 1 & In accordance with the Guidelines & 27 & 84,4 \\
\hline 2 & Not in Accordance with the Guidelines & 5 & 15,6 \\
\hline 3 & Total & 32 & 100.0 \\
\hline
\end{tabular}

Application of PIS PK the most appropriate guidelines which 27 (84.4\%) compared to not match the guidelines which 5 (15.6\%) of respondents.

Table 3. Frequency Distribution According To Patriarchal And Matriarchal Family Decision Making

\begin{tabular}{|l|l|l|l|}
\hline No & Decision-making & Amount & $\%$ \\
\hline 1 & Matriarchal & 20 & 62,5 \\
\hline 2 & Patriarchal & 12 & 37,5 \\
\hline 3 & Total & 32 & 100.0 \\
\hline
\end{tabular}

The decision of the mother's family (matriarchal) of respondents is more that 20 people $(62.5 \%)$ compared to the family decision of the father (patriarchal) which is 12 people.

Table 4. Frequency Distribution According To The Treatment Compliance Of Pulmonary TB Respondents

\begin{tabular}{|l|l|l|l|}
\hline No & Treatment Compliance & Amount & $\mathbf{\%}$ \\
\hline 1 & Obedient & 27 & 84.4 \\
\hline 2 & Not obey & 5 & 15.6 \\
\hline 3 & Total & 32 & 100.0 \\
\hline
\end{tabular}

The highest number of obedient pulmonary tuberculosis respondents were $27(84.3 \%)$ compared to 5 (15.6\%) disobedient.

Bivariate Analysis

Table 5. Cross Table of The Implementation Of PK PIS With Patriarchal And Matriarchal Decision Making Models For Family Members Affected By Lung TB In The Work Area Of The Remu Health Center In 2019

\begin{tabular}{|l|l|l|l|l|l|l|l|}
\hline \multirow{2}{*}{ NO } & \multirow{2}{*}{ Application of PIS PK } & \multicolumn{3}{|l|}{ Decision Making Model } & \multicolumn{2}{l}{ Total } \\
\cline { 3 - 8 } & & \multicolumn{2}{|l|}{ Patriarchal } & \multicolumn{2}{l|}{ Matriarchal } & \multicolumn{2}{l|}{} \\
\cline { 3 - 8 } & & $\mathbf{f}$ & $\%$ & $\mathbf{f}$ & $\%$ & $\mathbf{f}$ & $\%$ \\
\hline 1 & Corresponding & 9 & 33,3 & 18 & 66,7 & 27 & 100 \\
\hline 2 & It is not accordance & 3 & 60,0 & 2 & 40,0 & 5 & 100 \\
\hline & Total & 12 & 37,5 & 20 & 62,5 & 32 & 100 \\
\hline
\end{tabular}


Test Statistics Old ratio shows that the value of "Estimate" which means 8.333 application of PIS PK according to the guidelines in the decision-making matriarchal 8 times as much risk of the patriarchal decision making.
Asymp Value Sig (2-Sided) shows $\mathrm{p}$ value of $0,000<0.05$, so it can be concluded that there is a significance of the application of PIS PK with patriarchal and matriarchal decision making models in family members suffering from pulmonary TB in the working area of Remu Puskesmas in Sorong City.

Table 6. Cross Table The Application Of PIS PK To The Compliance Of Medical Treatment Of Family Members Suffering From Pulmonary TB In The Work Area Of The Remu Health Center In 2019

\begin{tabular}{|c|c|c|c|c|c|c|c|}
\hline \multirow{3}{*}{ No } & \multirow{3}{*}{ Application Of PIS PK } & \multicolumn{4}{|c|}{ Treatment Compliance } & \multirow{2}{*}{\multicolumn{2}{|c|}{ Total }} \\
\hline & & \multicolumn{2}{|c|}{ Obedient } & \multicolumn{2}{|c|}{ Not Obey } & & \\
\hline & & $\mathbf{F}$ & $\%$ & $\mathbf{F}$ & $\%$ & $\mathbf{F}$ & $\%$ \\
\hline 1 & Corresponding & 21 & 77.8 & 6 & 22.2 & 27 & 100 \\
\hline \multirow[t]{2}{*}{2} & It Is Not Accordance & 3 & 60.0 & 2 & 40.0 & 5 & 100 \\
\hline & Total & 27 & 84.4 & 5 & 15.6 & 32 & 100 \\
\hline
\end{tabular}

Test statistics old ratio shows that the value of "Estimate" which means 10.333 application of PIS PK according to the guidelines on treatment compliance risk is 10 times higher than in non-adherent treatment .

Asymp Value Sig (2-Sided) shows the p value 0.000 $<0.05$, it can be concluded that there is a significance to the application of PIS PK obedience treatment to family members who suffer from pulmonary $\mathrm{TB}$ in the region of Puskesmas Remu Sorong.

\section{Determination of Sub Themes}

Based on the coding process, determining sub themes, 5 themes are found:

6. They Have A Cross-Program Meeting Discussed The Results Of Family Visits At The Puskesmas Level And What Are The Documents

The informant said that the meeting had been held. The informant said that the document exists and available.
7. Constraints Found

The informant said that the obstacle found was that the house visit was not optimal.

8. Documents On The Results Of Family Visit Presentations At The Puskesmas Level And The Variables Included

The informant said that documents were available on the results of the family visit and the variables included were TB patients who had dropped out.

9. Disseminate The Presentation Of The Analysis Of The Family Visit And Form The Dissemination Is Carried Out

The informant said that repeated home visits had been carried out, but those dropouts still did not seek treatment again for various reasons. Infoman also said that there were some patients who did not want to take medicine.

10. Dissemination Constraints Found

Infoman said that there were some patients who 
did not want to take medicine. Informant said that he would announce the names of patients who did not seek treatment or coordinate further with cross-sectors.

\section{Discussion}

Implementation Of PIS PK (Healthy Indonesia Program) With Patriarchal And Matriarchal Decision Making Models Of Adherence To Family Members Suffering From Pulmonary TB In The Working Area Of Puskesmas Remu

Healthy Indonesia program became the main program of Health Development which then planned accomplishments through the Strategic Plan (Strategic Plan) Ministry of Health of the Year 2015-2019, established by Decree of the Minister of Health No. HK.02.02/Menkes/52/2015, Minister of Health, $2016^{2}$.

Family approach is one way to increase outreach to target health centers and perform/improve access to health care in their working area to visit family, Minister of Health ${ }^{2}$.

In the implementation of PIS PK, it has been carried out according to the guidelines with home visits, in fact many people responded well to the presence of PIS PK in the working area of the Sorong City Puskesmas Remu, but many people also refused to be treated. Repeated home visits have been carried out but the dropouts still do not seek treatment anymore by sharing reasons.

Implementation Of PIS PK (Healthy Indonesia Program) With The Model Of Patriarchal And Matriarchal Decision Making In Family Members Who Suffer From Pulmonary TB In The Working Area Of The Puskesmas Remu Sorong City

The results showed application of PIS PK according to the guidelines in the decision-making matriarchal 8 times as much risk of the decision-making patriaka 1 . In get value $p$ value $0.000<0.05$, it can be concluded that there is a significance the application of PIS PK with decision-making model of patriarchal and matriarchal family members who suffer from pulmonary TB in the region of Puskesmas Remu Sorong, almost similar to the research study $\square$ that viewpoint in family decisions are mainly taken from family members with direct parenting duties.
The model of family decision making in dealing with family members suffering from pulmonary TB in the working area of the Puskesmas Remu is $62.5 \%$ dominant in mothers (matriarchal). According to the researchers' assumptions, it is in accordance with the culture of the local community where the decision maker decides to listen more to a wife or mother. This is because there are decisive aspects in making decisions such as: the type of household work, office work, family needs, basic needs and additional equipment and facilities available in the family, the time and energy available, which dominates is the mother. Mothers have the feeling high worried when a family member is sick, so the phenomenon in found that the mother is to play a role in encouraging and motivating family members who suffer from pulmonary tuberculosis, even the existing situation the mother also act as watchdogs to take medication pulmonary tuberculosis.

\section{Application of PIS PK (Healthy Indonesia} Program) To The Compliance Of Medical Treatment Of Family Members Suffering From Pulmonary TB

The results showed estimate the value of 10.333 means application of PIS PK according to the guidelines on treatment compliance risk is 10 times more than the non-adherent treatment and get the value asymp show $0,000 \mathrm{p}$ value $<0.05$, it can be concluded that there is no significance to the application of PIS PK treatment Compliance in family members suffering from pulmonary TB in the working area of the Sorong City Puskesmas Remu.

As many as 32 respondents, most of them (84.4\%) were obedient in undergoing treatment for pulmonary TB that lasted 6 months. According to the researchers' assumptions, because respondents were still in the category 1 treatment $(87.5 \%$ ), apart from that many family members who adhered to TB treatment because of family support in this case the mother (wife), the mother was able to make decisions, the family in terms of this mother is able to care for family members who experience health problems, mothers are able to encourage families to seek treatment at existing health facilities in order to deal with health problems in this case the treatment of pulmonary TB. Besides family members who visited regularly influenced by the level of education in which the vast majority were high school 
$(37.6 \%)$.

According to the researchers' assumptions that the obstacles found were not optimal, the visits were made, due to lack of time and human resources. The existence of TB patients who drop out because the patient feels bored with the consumption of taking large amounts of medicine and for a long period of time, so that patients think to stop taking the drug and switch to other treatments, such as herbal medicine ${ }^{10,11}$. Besides that, it can also be influenced by socio-economy in this case the work of family members who are mostly self-employed (40.6\%) where this work takes time to fulfill their living needs.

\section{Conclusions}

Based on the results of the research, it can be concluded :

4. Application of PIS PK (Program Healthy Indonesia) pulmonary $\mathrm{TB}$ disease in the region of Puskesmas Remu has been done and have the document. But in practice, there are obstacles that are not yet a maximum of home visits, and patients are lazy to take medication.

5. It was concluded that there was a significance of the implementation of PIS PK with Patriarchal and Matriarchal Decision Making Models in family members suffering from pulmonary TB in the working area of Remu Puskesmas in Sorong City

6. There is a significance of the implementation of PIS PK with Compliance with treatment to family members who suffer from pulmonary TB in the working area of the Puskesmas Remu in Sorong City.

Ethical Clearance- Taken from university ethical committee
Source of Funding- Self

Conflict of Interest - Nil

\section{References}

1. Ministry of Health . Healthy Indonesia Program with Guidebooks . 2016. kemenkes.go.id

2. Fauzan, A. Implementation of a Healthy Indonesia Program with a Family Approach (PIS-PK) at the Mulyaharja Health Center. Journal of Public Health Students , 2 (3), 172-181. 2019. Retrieved from http://ejournal.uika-bogor.ac.id/index.php/ PROMOTOR

3. Infodatin.kemkes.go.id/article/view/18101500001/ infodatin-tuberkulosis-.html . 2017

4. West Papua Health Profile. 2017

5. Maria . Family Nursing Care. Mahardika Library . Yogyakarta : 2018

6. Febriani, VD Manuscript publication . 2014

7. Profile of Puskesmas Remu, Sorong City . 2019

8. Agni, MGK, Yogyakarta Special Region Readiness in Implementing a Healthy Indonesia Program with a Family Approach. Formal Journal , 3 (1), 1-5. .https://doi.org/http://pispk.kemkes.go.id/en/.2018

9. Foley, G., \& Hynes, G. Decision-making among patients and their families in ALS care: a review. Amyotrophic Lateral Sclerosis and Frontotemporal Degeneration , 19 (3-4), 173-193. 2018

10. Anshar, M., Tahir, D., Makhrani, Ani, F.N., Mallongi, A., Analysis of effectiveness in addition of coffee and brown sugar on wastewater treatment in regional, ARPN Journal of Engineering and Applied Sciences, vol: 14, issue : 7, 2019-04-01.

11. Sandu Siyoto, Anwar Mallongi, Muh Irfan Ilham, Syamsiar Russeng, Mustafa. Target Cancer Risks of Exposure to Carbon Monoxide and Plumbum among Attendants of Parking Lots in Panakkukang Mall and Panakkukang Square Makassar City. SRP. 2019; 10(1): 151155. doi:10.5530/srp.2019.1.28 